\title{
PENGENTASAN KEMISKINAN DAN PENGEMBANGAN MASYARAKAT MELALUI MODEL KEUANGAN ISLAM BMT AL-ISHLAH CIREBON
}

\author{
Muhammad Awaluddin Ardiansyah ${ }^{1}$ \\ Department of Economics, Faculty of Economics Andi Djemma University \\ muh.awalardiansyah@gmail.com
}

\begin{abstract}
Although in fact the conventional financial sistem has manifestly failed in the fair distribution of wealth, but Islamic financial sistem in Indonesia is not a strong alternative financial sistem. Market share of Islamic financial institutions are still low below 5\% with growth of $34 \%$ in 2015. The data indicates the existence of problems in the implementation of the principles of Islamic finance though in terms of potential prospects. Islamic economic principles which have a charge values of justice, divinity, freedom and responsibility, the right should be a sistem of democratic economy in the economic empowerment of the poor. Some of the reasons based on the analysis of the field to be the cause of them; The first people are still accustomed to a conventional sistem that has been around longer, the second Islamic financial institutions are not ready completely adopt the Islamic financial sistem in particular lost Pofit product sharing (PLS), the third implementation of Islamic financial institutions require relatively high operating costs. On the above problems, the authors analyzed qualitatively descriptive of a theme study "Al-Islah BMT Cirebon as Islamic Financing Model for Poverty Reduction and Development". An analysis of the terms of the Muamalat Islamic law and court analyzes considering the author as a community development agency practitioners who use Islamic financial institutions Baitul Maat wa Tamwil (BMT) in technical operations. This simple paper notes that Islamic financial institutions in Indonesia has not fully practice the principles of Islamic finance because of certain interests. That has existed in Indonesia an Islamic financial institution which according to the principles of Islam in practice the empowerment of people out of poverty.
\end{abstract}

Keywords: Community Development; Islamic Finance; Micro Finance Institutions; Poverty

\section{PENDAHULUAN}

Telah jelas, penetapan sistem bunga dari mulai bank sentral turun ke bank umum hingga ke lembaga keuang mikro, bunga bank menjadi mata rantai eksploitasi yang makin besar saat menyentuh masyarakat miskin yang tidak bankable. Sistem keuangan islam merupakan sistem yang tidak menghadirkan bunga namun menghadirkan zakat. Dalam keuangan islam bunga bank digantikan dengan bagi hasil, kedua belah pihak yang bertransaksi baik itu pemodal dan pengelola siap menanggung kemungkinan profit atau rugi. Selain itu zakat menjadi konsekuensi kedua belah pihak menyisisihkan dan menyerahkan kepada lembaga pengelola yang dialokasikan untuk 8 penyandang masalah kesejahteraan sosial.

Masyarakat Indonesia dalam memahami sistem keuangan islam, masih terbiasa dengan sistem konvensional yang telah lama ada. Pemahaman akan sistem keuangan islam baru sebatas kompersi istilah. Secara awam masyarakat mengidentifikasi lembaga keuangan/bank syariah sebagai berikut; bahwa tidak menggunakan istilah bunga melainkan margin, bahwa ada nama-nama produk tapi tidak benar benar faham makna dan perbedaannya, adanya persepsi margin pada produk lending di lembaga keuangan syariah yang lebih mahal daripada di lembaga keuangan konvensional, adanya 
sikap eklektik atas pengalaman masyarakat membandingkan lembaga keuangan islam dan konvensional yaitu "jika menabung di bank syariah namun jika meminjam di bank konvensional". Pemahaman masyarakat tentang lembaga keuangan syariah diatas merupakan akibat dari informasi yang mereka dapatkan saat mendatangi perbankan/lembaga keuangan syariah.

Kekeliruan umum tersebut dilatari oleh perbankan/lembaga keuangan syariah di Indonesia yang cenderung hanya menawarkan produk murobahah dalam penyaluran dananya, dimana murobahah menghasilkan profit bagi bank/lembaga keuangan syariah berupa margin. Penetapan margin menggunakan acuan bunga bank bahkan bisa juga lebih besar untuk transaksi barang yang memiliki resiko tinggi. Murobahah merupakan jenis transaksi jual beli yang tidak menggunakan konsep profit dand lost sharing (PLS) Sikap lembaga keuangan yang lebih condong pada produk murobahah dalam pembiayaan, merupakan reaksi atas kepercayaan yang kurang terhadap masyarakat, sehingga dikhawatirkan tidak dapat mengembalikan modal pinjaman. Berikut produk murobahah yang disalurkan perbankan syariah umum tahun 2016.

Tabel 1.Penyaluran dana perbankan syariah Indonesia(Data SPS OJK 2016 Diolah)

\begin{tabular}{lrr}
\hline \multicolumn{1}{c}{ Akad } & Juni 2016 & Persen \\
\hline Mudharabah & 182.677 & $3 \%$ \\
\hline Musyarakah & 764.862 & $12 \%$ \\
\hline Murabahah & 4.927 .903 & $78 \%$ \\
\hline Salam & 14 & $0 \%$ \\
\hline Istishna & 9.388 & $0 \%$ \\
\hline Ijarah & 7.508 & $0 \%$ \\
\hline Qardh & 139.772 & $2 \%$ \\
\hline Multijasa & 431.711 & $6 \%$ \\
\hline Jumlah & $\mathbf{6 . 4 6 3 . 8 3 4}$ & $\mathbf{1 0 0}$ \\
\hline
\end{tabular}

Berdasarkan data diatas menunjukan produk murobahah menjadi produk utama penyaluran dana perbankan syariah di Indonesia. Data diatas menjadi indikator kegamangan perbankan syariah untuk secara total menerapkan prinsip keuangan islam yang menggunakan profit and lost sharing
(PLS) dalam perolehan keuntungan. Penggunaan akad murabahah untuk membiayai modal kerja yang sifatnya berputar dalam kegiatan usaha adalah bentuk penyimpangan dan tidak tepat memahami bank syariah sebagai bank bagi hasil. Sedangkan dalam penarikan dana fihak ketiga (nasabah/deposan) perbankan syariah bersedia menerapkan produk selain murobahah yakni mudhorobah dan musyarokah.

Metode yang dilakukan pada paper ini menggunakan analisis deskripsi. sumber data berasal dari laporan statistik perbankan dan keuangan syariah periode 3 tahun hingga Juni 2016 yang dibandingkan dengan laporan keuangan BMT Al-Ishlah 3 tahun terakhir (2013, 2014, 2015). Dari data analisis keuangan dilakukan konfirmasi secara langsung pada management BMT. Adapun penjabaran paper ini mengikuti kerangka teori pikir sebagai berikut : pertama mengutip beberapa prinsip teori keuangan syariah, kedua mengkonfirmasi implementasi prinsip keuangan syariah dari analisis data keuangan dan wawancara, ketiga menyuguhkan data pembangunan komunitas di Cirebon yang dikelola secara terintegrasi dengan BMT dan telah berjalan cukup lama.

Tujuan Penelitian, (1) Untuk mengetahui efektifitas penerapan model sistem keuangan Islam pada masyarakat Cirebon melalui BMT Al-Islah. (2) Untuk mengukur tingkat keberhasilan sistem keuangan islam dalam peningkatan ekonomi (pendapatan dan tabungan) masyarakat Cirebon. (3) Untuk mengetahui pengaruh jangka panjang penerapan sistem keuangan islam dan penerapannya untuk daerah-daerah lain.

\section{Prinsip Keuangan Islam dalam Praktek Keuangan Islam}

Nilai-nilai islam dalam seluruh aspek kehidupan telah tertulis dalam kitab dan buku-buku keislaman. Muamalah merupakan aturan hukum antar sesama manusia dalam bersosial ekonomi dan antar manusia dengan lingkungan lain disekitarnya. Untuk permasalahan muamalah baru yang belum tertulis dalam kitab Al Quran atau Sunnah, 
diberikan cara ijtihad yang dilakukan oleh ahli hukum islam yang tetap mengacu pada penafsiran quran dan sunnah yang sama. Hukum dasar muamalah itu mubah atau boleh. Artinya manusia boleh melakukan upaya inovasi dan kreatifitas produk dan tehnologi yang terus berkembang dalam urusan sosial ekonomi, sehingga tidak menentang etika yang telah ditetapkan dalam Al-Quran dan Sunnah.

Tiga pilar utama ekonomi Islam adalah implementasi zakat, pelarangan riba, dan pelarangan maysir/gharar (gambling). Secara ekonomi, implementasi sistem zakat akan meningkatkan permintaan agregat dan mendorong harta mengalir ke dalam investasi, pelarangan riba akan menjamin aliran investasi menjadi optimal dan tidak terbendung, sedangkan pelarangan maysir akan memastikan investasi mengalir ke sektor riil untuk tujuan produktif yang akhirnya akan meningkatkan penawaran agregat.

Pada implementasi kegiatan ekonomi Islam baik sektor riil maupun keuangan, empat hal dibawah ini menjadi prinsip yang harus tetap terjaga, diantaranya : PLS + HT $+\mathbf{Z}+\mathbf{W}$

Profit and Lost Sharing (PLS) : sistem investasi berdasar atas pembagian laba dan rugi antar mereka yang berakad. Profit and Lost Sharing merupakan solusi dari peniadaan riba. Adapun produk keuangan Islam yang telah ada saat ini sebagai berikut : Mudharabah, Musyarakah, Murabahah, Salam, Istishna, Ijarah, Qardh dan Multi jasa lainya.

Halal dan Thoyib (HT) : komoditi yang diusahakan bersama adalah yang halal dan bermanfaat, baik secara dzat produk maupun secara proses perolehan. Kehalalan dzat dari suatu benda, telah jelas ditentukan dalam nash Al-Qur'an dan As-Sunnah. Pada dasarnya teramat banyak barang atau makanan yang halal untuk dimiliki atau dikonsumsi dan hanya beberapa saja yang diharamkan diantaranya minuman yang memabukan, daging babi, berhubungan intim antara pria dan wanita tanpa ikatan pernikahan, larangan durhaka kepada orang tua dan larangan memuja Tuhan selain Allah. Kehalalan dalam proses perolehan keuntungan atau kepemilikan harta, Islam menetapkan etika yang mengedepankan nilai-nilai positif seperti larangan menimbun, larangan memotong siklus pasar terbuka, larangan gambling/ketidakpastian, larangan dholim, larangan berlebihan, larangan mempersulit, anjuran memberi tempo pembayaran, anjuran mencatat transaksi tunda, anjuran persaksian/pendampingan dalam transaksi, anjuran membayar upah segera dan anjuran memaafkan. Beberapa etika diatas selanjutnya menjadi standar indikator Majlis Ulama Indonesia (MUI) dalam memberikan fatwa produk-produk bisnis dan keuangan islam.

Zakat (Z) : setiap muakid baik pengelola maupun pemodal mengeluarkan zakat. Pada zakat terdapat dampak keseimbangan sistem keuangan. Dana zakat yang disetorkan oleh nasabah funding dan nasabah lending dalam pendistribusianya melalui lembaga keuangan islam yang juga mengelola bidang pelayanan sosial yang dinamakan Baitul Maal(BM).

Weigh (W) : upah dibayarkan sebelum keringat kering memiliki makna pemberian hak pekerja sesuai kinerja dan mencukupi kebutuhan dasar hidup pekerja. Upah dalam sistem ekonomi Islam tidak bisa dilepaskan dengan peningkatan produktifitas. Untuk memaksimalkan keuntungan (maximizing profit) pekerja menjadi penentu melalui meningkatkan jumlah produk yang akan berdampak pada peningkatan pendapatan pekerja sekaligus peningkatan profit perusahaan. Sebaliknya untuk minimizing cost, upah tidak menjadi variabel yang ditekan sehingga merugikan atau mendholimi pekerja namun menggunakan solusi teknologi yang telah nyata dapat menekan biaya operasional.

Keuangan islam merupakan sistem bukan agama yang dapat digunakan dan dioperasikan oleh siapapun dan komunitas apapun untuk program pengurangan kemiskinan dan pembangunan ekonomi komunitas. Terdapat empat kategori dasar produk keuangan islam. Pertama mode berbasis kerjasama yaitu mudhorobah dan 
musyarokah. Kedua mode berbasis perdagangan seperti murobahah, musawamah, salam dan istisna. Ketiga mode berbasis sewa seperti ijaroh. Keempat mode berbasis chariti dan jasa lain seperti qord hasan,wakalah, waqaf, zakat, infaq.

\section{Lembaga Keuangan Islam dan Produk Jasa Keuangan Islam}

Lembaga keuangan islam mempunyai dua peran utama, yaitu sebagai badan usaha(tamwil) dan badan sosial (maal). Sebagai badan usaha, bank syariah mempunyai beberapa fungsi, yaitu sebagai manajer investasi, investor dan jasa pelayanan. Sebagai manajer investasi, bank syariah melakukan penghimpunan dana dari para investor/nasabahnya dengan prinsip wadi'ah yad dhamanah (titipan), mudharabah (bagi hasil) atau ijarah (sewa). Sebagai investor, bank syariah melakukan penyaluran dana melalui kegiatan investasi dengan prinsip bagi hasil, jual beli, atau sewa. Sebagai penyedia jasa perbankan, bank syariah menyediakan jasa keuangan, jasa non keuangan, dan jasa keagenan. Pelayanan jasa keuangan antara lain dilakukan dengan prinsip wakalah (pemberian mandat), kafalah (bank garansi), hiwalah (pengalihan utang), rahn (jaminan utang atau gadai), qardh (pinjaman kebajikan untuk dana talangan), sharf (jual beli valuta asing), dan lain-lain. Pelayanan jasa non keuangan dalam bentuk wadi'ah yad amanah ( safe deposit box ) dan pelayanan jasa keagenan dengan prinsip mudharabah muqayyadah. Sementara itu, sebagai badan sosial, bank syariah mempunyai fungsi sebagai pengelola dana sosial untuk penghimpunan dan penyaluran zakat, infak, dan sadaqah (ZIS), serta penyaluran qardhul hasan (pinjaman kebajikan). Secara umum lembaga keuangan bergerak dalam bidang keuangan (sektor moneter) sesuai dengan ketentuan BI, bank tidak diperkenankan melakukan kegiatan usaha diluar core bisnisnya yaitu dibidang keuangan. Berdasarkan beberapa produk keuangan islam, lembaga keuangan islam selain melaksanakan core bisnisnya pada moneter juga bisa melayani pelayanan terkait pembayaran seperti assuransi, gadai, leasing dan kerjasama bisnis lainnya.

Tabel 2. Sistem lembaga keuanga islam, diolah dari berbagai sumber.

\begin{tabular}{llll}
\hline & \multicolumn{2}{c}{ TAMWIL } & \multicolumn{1}{c}{ BAITUL } \\
MAAL
\end{tabular}

Divisi Baitul Maal selain pelayanan charity juga melakukan pembinaan calon nasabah yang direkomendasikan ke Tamwil bagai mustahik yang lancar dan jurur dalam pengembalian qordul hasan. Produk keuangan syariah diatas pernah diimplementasikan pada masa rosulullah saw, pada masa sahabat dan produk kontemporer kekinian yang masih relevan dengan prinsip keuangan islam dan telah melalui proses ijtihad para ulama. Dari beberapa produk diatas, terdapat turunan produk yang lebih spesifik dengan perbedaan pengembanganya.

\section{METODE PENELITIAN}

Dalam penelitian ini, penulis menggunakan metode berdasarkan tempat penelitian, lebih tepatnya menggunakan jenis penelitian Field Reseach (penelitian lapangan) yaitu penelitian yang dilaksanakan langsung dilapangan. Obyeknya yaitu mengenai gejala-gejala, peristiwa dan fenomena-fenomena yang terjadi di lingkungan sekitar, baik masyarakat, 
organisasi lembaga dan bersifat nonpustaka. Maka dari itu, dalam pembahasan ini penulis akan melakukan penelitian tentang penerapan model keuangan islam di BMT Al-Islah Cirebon, dengan respondennya yaitu pengelola, dan Masyarakat yang menggunakan pinjaman melalui sistem keuangan islam di Institusi keuangan mikro tersebut. Proses pengolahan data dilakukan dalam dua tahap, pertama pada wawancara sebelum datanya dientry untuk dianalisis dan tahap kedua dilakukan sesudah di-entry. Editing data dimaksudkan untuk mengurangi kesalahan pada data secara individual, mengurangi sifat keaneka ragaman, sehingga pada ahirnya dapat diolah secara mudah.

Analisis data dimulai dengan menelaah seluruh data yang tersedia. Dalam penelitian ini penyusun mengumpulkan data yang sudah digali oleh penyusun selama penelitian. Berupa hasil wawancara dan dokumentasi penelitian.

Penafsiran data yaitu pencarian pengertian yang lebih dalam dan luas tentang temuantemuan dalam penelitian. Penyusun menafsirkan data yang telah di analisis dengan cara mendiskusikan temuan-temuan selama penelitian. Dan kemudian penyususn akan menarik kesimpulan yang bisa menjawab rumusan masalah.

\section{HASIL DAN PEMBAHASAN Bagaimanakah Praktek Keuangan Islam dalam Mengurangi Kemiskinan dan Pembangunan?}

Baitul Maal wa Tamwil (BMT) sebuah konsep lembaga keuangan islam mikro yang jangkauannya hingga ke pelosok pedesaan. BMT sebuah lembaga keuangan yang menjadi unit usaha Koperasi mengsyaratkan keanggotaan dengan tujuan usaha bersama pelayanan keuangan. Lembaga keuangan yang menggunakan prinsip keuangan islam ini didirikan tahun 1980 melalui uji coba Baitut Tamwil Salman Bandung, yang didirikan oleh Para tokoh yang terlibat ; Karnaen A.Perwataatmaja, M. Dawam Rahardjo, A.M. Saefuddin, M.Amin Azis, dll.
BMT Al-Ishlah Cirebon (selanjutnya ditulis BMT AC), sebuah lembaga keuangan mikro islam berdiri tahun 1990. Lembaga keuangan Islam salah satu dari unit usaha Koperasi Pondok Pesantren (KOPONTREN) Al-Ishlah, saat pendiriannya bermodalkan uang simpanan wajib dan simpanan pokok anggota sebesar Rp 10.000.000 ( sepuluh juta rupiah). Saat ini BMT AC telah memiliki 6 unit kantor kas di Kabupaten Kuningan, Kabupatgen Majalengka, Kabupaten Indramayu, Arjawinangun Cirebon, Plumbon Cirebon dan Kantor Perdana di Desa Bobos Cirebon. Dengan asset saat ini telah mencapai $\mathrm{Rp}$ 11.209.305.803. Bagaimanakah BMT AC yang telah 26 tahun mempraktekan sistem keuangan Islam?

\section{Pendanaan (funding) BMT AC}

Sebagai lembaga keuangan mikro islam dibawah naungan Koperasi, BMT Memungut dana dari simpanan wajib, simpanan pokok anggota. Selain itu simpanan sukarela lain yang ditawarkan berdasarkan produk simpanan yang dibutuhkan oleh masyarakat. Total jumlah simpanan dari anggota/nasabah BMT AC pada tahun 2015 adalah sebesar sebesar $63 \%$ dari total dana produktif BMT. Dana dari pihak ketiga lainnya berasal dari penyertaan modal Koperasi Al-Ishlah sebesar sebesar 13,8 \%, dana perbankan umum syariah 10,8\% dan dana asosiasi Koperasi syariah 14,5 \% dari total dana produktif BMT. Berikut nama-nama jenis simpanan anggota : 
Tabel 3. Jenis simpanan anggota BMT AC 2015 diolah.

\begin{tabular}{|c|c|c|c|}
\hline No. & $\begin{array}{l}\text { Nama } \\
\text { simpanan }\end{array}$ & $\begin{array}{l}\text { Jumlah } \\
\text { Rekening }\end{array}$ & $\begin{array}{l}\text { Rasio } \\
\text { simpan } \\
\text { an }\end{array}$ \\
\hline 1. & Simpanan wajib & 1.495 & $2.88 \%$ \\
\hline 2. & Simpanan pokok & 1.493 & $0.53 \%$ \\
\hline 3. & $\begin{array}{l}\text { Simpanan pokok } \\
\text { calon anggota }\end{array}$ & 4.709 & $0.52 \%$ \\
\hline 4. & $\begin{array}{l}\text { Simpanan } \\
\text { walimah }\end{array}$ & 40 & $0.11 \%$ \\
\hline 5. & $\begin{array}{l}\text { Simpanan hari } \\
\text { tua }\end{array}$ & 0 & $0.00 \%$ \\
\hline 6. & $\begin{array}{l}\text { Simpanan } \\
\text { pendidikan }\end{array}$ & 260 & $7.07 \%$ \\
\hline 7. & $\begin{array}{l}\text { Simpanan } \\
\text { madinah }\end{array}$ & 4.360 & $\begin{array}{l}62.98 \\
\% \\
\end{array}$ \\
\hline 8. & $\begin{array}{l}\text { Simpanan idul } \\
\text { fitri }\end{array}$ & 837 & $\begin{array}{l}12.58 \\
\%\end{array}$ \\
\hline 9. & $\begin{array}{l}\text { Simpanan } \\
\text { qurban }\end{array}$ & 50 & $0.12 \%$ \\
\hline 10 & Simpanan haji & 25 & $0.59 \%$ \\
\hline 10. & Simpanan ZIS & 0 & $0.00 \%$ \\
\hline 11. & $\begin{array}{l}\text { Simpanan } \\
\text { wadiah }\end{array}$ & 3.202 & $\begin{array}{l}12.62 \\
\%\end{array}$ \\
\hline 12. & Simpanan RAK & 0 & $0.00 \%$ \\
\hline 13. & $\begin{array}{l}\text { Simpanan Vip } \\
\text { Mobile }\end{array}$ & 0 & $0.00 \%$ \\
\hline \multicolumn{2}{|c|}{ Jumlah anggota } & 16.471 & $100 \%$ \\
\hline
\end{tabular}

Keuntungan yang diberikan BMT kepada pemilik modal berupa bagi hasil dari margin/profit yang diterima sesuai dengan nisbah yang disepakati, setelah dikurangi biaya. Berdasarkan tabel ditas dapat dilihat rasio bagi hasil (Basil) pemilik dana dari keuntungan bersih rata-rata $58 \%$ dengan rasio pertahun berbeda-beda $69 \%$ tahun 2013, $48 \%$ tahun 2014 dan $64 \%$ tahun 2015. Perolehan nisbah Basil setiap tahun besaranya tidak konsisten, hal ini disebabkan perbedaan nisbah setiap produk sesuai berdasarkan volume usaha, besaran modal dan waktu peminjaman, perlu adanya pengawas kesesuaian Basil yang telah disepakati dalam akad.

Jika membandingkan hasil sistem keuangan islam BMT AC dengan Bunga sistem konvensional, dapat dilihat sebagai berikut : total angka perolehan nisbah bagi hasil pemilik modal rata-rata selama 3 tahun
$58 \%$ dari keuntungan bersih, berarti setara dengan $12 \%$ dari pendapatan kotor, setara dengan 3,6\% dari modal yang dipinjamkan.

Biaya operasional rata-rata yang dialokasikan sebesar $79 \%$, hal ini mengindikasikan tingginya biaya yang mengurangi keuntungan, karena nisbah bagi hasil dari keuntungan bersih. Biaya operasional dapat menjadi peluang kesewenangan lembaga pengelola keuangan jika tidak menetapkan standar ideal dalam SOP keuangan lembaga yang juga diketahui oleh pemilik dana. Dalam kasus diatas, pemilik dana dalam posisi ini tidak memiliki kepastian keuntungan maksimal. Berikut income statement BMT AI tahun 2015 :

Tabel 4. Income statement BMT AC

\begin{tabular}{ll}
\hline Keterangan & Percent \\
\hline Income & $\begin{array}{l}29 \% \text { dari dana } \\
\text { Fund }\end{array}$ \\
\hline $\begin{array}{l}\text { Expense } \\
\text { Operational Cost } \\
\text { Bagi hasil }\end{array}$ & $\begin{array}{l}79 \% \text { dari } \\
\text { Income }\end{array}$ \\
\hline $\begin{array}{l}\text { Earning before } \\
\text { Zakat (EBZ) }\end{array}$ & $21 \%$ \\
\hline Zakat & $2,50 \%$ \\
\hline Net income BMT & $21 \%$ \\
\hline \multicolumn{2}{l}{ Dari keuntungan bersih selanjutnya Sisa }
\end{tabular}
Hasil Usaha (SHU) dibagikan untuk alokasi sebagai berikut ; cadangan modal, anggota, pengawas, pengurus kopontren, pengelola BMT, karyawan, sosial, pembangunan daerah dan audit.

Pembiayaan (Lending) BMT AC

Adapun dalam penyaluran dana atau pembiayaan, BMT AC seperti halnya perbankan syariah di Indonesia secara umum, produk Murobahah menjadi produk yang dipilih oleh para peminjam. Hal ini didasari oleh kurangnya pemahaman produk dan masih terbiasa dengan produk konvensional. Selain itu marketing dan front ofice BMT AC cenderung menawarkan produk Murobahah dibandingkan produk lain. Suatu keputusan yang didasari pada ke hati-hatian menyalurkan dana pihak ketiga karena faktor kepercayaan kepada nasabah lending dalam kemampuan pengelolaan dana pinjaman, simpel dan tidak berbiaya tinggi. 
Tabel 5. Produk pembiayaan BMT AC Jumlah dana pembiayaan yang diserap oleh peminjam dan standar margin

\begin{tabular}{llcc}
\hline No & $\begin{array}{l}\text { Nama Produk } \\
\text { Pembiayaan }\end{array}$ & $\begin{array}{l}\text { Jumlah } \\
\text { Rekening }\end{array}$ & $\begin{array}{l}\text { Rasio } \\
\text { Pembiayaan }\end{array}$ \\
\hline 1. & Mudharabah & 0 & $0.00 \%$ \\
\hline 2. & Musyarakah & 262 & $7.55 \%$ \\
\hline 3. & Murabahah & 1.064 & $71.15 \%$ \\
\hline 4. & Bai Bitaman Ajil & 0 & $0.00 \%$ \\
\hline 5. & Multijasa umum & 1 & $0.61 \%$ \\
\hline 6. & Rahn & 0 & $0.00 \%$ \\
\hline 7. & Piutang Multijasa & 137 & $7.90 \%$ \\
\hline 8. & Qordul hasan & 124 & $9.51 \%$ \\
\hline 9. & Ijaroh Muntahia & 0 & $0.00 \%$ \\
& bitamlik & & \\
\hline 10 & Hawalah & 2 & $3.08 \%$ \\
\hline Jumlah & $\mathbf{1 . 6 1 0}$ & $\mathbf{1 0 0 \%}$ \\
\hline
\end{tabular}

Tabel 6. Margin pembiayaan BMT AC

\begin{tabular}{llll}
\hline Tahun & $\begin{array}{l}\text { Dana } \\
\text { Pembiayaan }\end{array}$ & $\begin{array}{l}\text { Pendapatan } \\
\text { Pembiayaan }\end{array}$ & Margin \\
\hline 2013 & 5.998 .152 .828 & 1.442 .164 .547 & $24 \%$ \\
\hline 2014 & 7.692 .547 .584 & 1.973 .1943728 & $26 \%$ \\
\hline 2015 & 8.332 .047 .337 & 2.010 .577 .372 & $24 \%$ \\
\hline Jumlah & $\mathbf{2 2 . 0 2 2 . 7 4 7 . 7 4 9}$ & $\mathbf{5 . 4 2 5 . 9 3 6 . 6 4 7}$ & \\
\hline
\end{tabular}

\section{Akad di BMT Al-Ishlah}

Proses penyaluran pada lembaga keuangan islam BMT Al-Ishlah Cirebon, sama dengan proses di lembaga keuangan mikro lainnya, yaitu nasabah datang ke lembaga keuangan, mengisi formulir atau aplikasi yang telah disediakan dan melakukan wawancara antara nasabah dengan pihak lembaga. Setelah itu dari pihak lembaga mensurvey ke tempat usaha dan tempat tinggal nasabah untuk memastikan usaha yang dijalankan nasabah, setelah itu pihak BMT merapatkan untuk memutuskan apakah pengajuan diterima atau ditolak. Penyaluran pembiayaan menurut sektor yang paling banyak adalah dalam bidang perdagangan atau jual beli (murobahah), sedangkan menurut besarnya pembiayaan, nasabah BMT antara 1 juta sampai 50 juta. Proses akad akan dilakukan saat pencairan dengan form yang sudah tertulis dan tersedia. Dalam posisi ini peminjam atau penabung cukup mengetahui dan menyetujui perjanjian yang telah tertuang dalam form perjanjan yang dilegalkan dengan penandatanganan diatas materai.

\section{Seberapa Besar Praktek Keuangan Islam} BMT AC dalam Pengurangan Kemiskinan dan Pembangunan ?

BMT Al-Ishlah Cirebon merupakan salah satu tool Yayasan Islama Al-Ishlah yang berdiri tahun 1974. Sesuai dengan visinya menciptakan generasi muslim yang paripurna menuju masyarakat idaman. Selain menyelenggarakan pendidikan dari tingkat dasar hingga sekolah tinggi ekonomi islam, juga menyelenggarakan lembaga ekonomi yang memiliki tujuan memenuhi kebutuhan dana pengembangan komunitas yang diselenggarakan Yayasan. BMT sebagai lembaga usaha yang menghimpun dana menjadi tujuan dalam solusi keuangan atas permasalahan keuangan unit-unit lembaga di Al-Ishlah yakni 8 unit lembaga pendidikan, 2 unit lembaga sosial dan 5 unit usaha sehingga lancar dalam operasional dan dapat berkembang. Secara tidak langsung BMT juga berperan dalam pengurangan kemiskinan dan pembangunan di wilayah Cirebon Jawa Barat hingga tahun 2015, dengan data sebagai berikut:

Tabel 7. Pemberdayaan BMT AC

\begin{tabular}{|c|c|}
\hline \multicolumn{2}{|l|}{ Keterangan } \\
\hline & \\
\hline Saving & 16.471 Rekening \\
\hline Lending & 1.610 Rekening \\
\hline Charity BM & $\mathrm{Rp} \quad 354.582 .680,-$ \\
\hline $\begin{array}{l}\text { Penyaluran lending } 3 \\
\text { tahun terakhir }\end{array}$ & Rp 22.022.747.749,- \\
\hline Tenaga Kerja & 35 orang \\
\hline $\begin{array}{l}\text { Keagenan Vip Mobile } \\
\text { (agen dan loket) }\end{array}$ & $502 \mathrm{Ang}$ \\
\hline
\end{tabular}

\section{KESIMPULAN}

Dari pembahasan diatas, dapat ditarik beberapa kesimpulan sebagai berikut :

a. Kecondongan produk yang ditawarkan oleh lembaga keuangan islam pada produk lending adalah murobahah. Hal ini didasari oleh kehati-hatian dalam menghindari kerugian. Namun demikian lembaga keuangan tidak menghadirkan barang yang ditransaksikan dan mempercayakan pembelian barang kepada kreditur dengan akad baru wakalah. Kerap 
terjadi ketidaksesuaian penggunaan dana oleh kreditur dari akad sebelumnya.

b. Keuntungan lending produk murobahah menstandarkan besaran margin pada standar angka $24 \%$. Hal ini didasari oleh perhitungan biaya operasional/asset, magin minimal, investasi, portofolio kredit bermasalah, target keuntungan dan harga kompetitor.

c. Keuntungan pemilik modal (funding) telah menggunakan prinsip bagi hasil dari keuntungan bersih dengan nisbah yang berbeda sesuai produk dan waktu. Perhitungan waktu nisbah harian sesuai dengan perolehan saat itu (cash basic).

d. Monitoring pasca pencairan bagi kreditur yang akad pembayaranya bulanan. Dilakukan saat kreditur mengalami kemacetan pembayaran. Berbeda dengan kreditur smaal micro, Basil dan saving dilakukan setiap hari setelah masa penggunaan dana pinjaman 3 hari.

e. BMT Al-Ishlah di Kabupaten Cirebon Jawa Barat Indonesia, telah dapat berpartisipasi dalam pengentasan kemiskinan terhadap 16.471 orang, melalui program saving pendidikan, hari tua, walimah, haji, qurban, idul fitri dan assuransi. Turut mengembankan 1.610 UKM melalui pembiayaan modal usaha, keagenan Vip mobile 502 agen dan santunan kepada penyandang masalah kesejahteraan sosial melalui dana Baitul Maal Rp 354.582.680.

\section{REFERENSI}

Asykarya. 2006. Akad dan Produk Bank Syariah, Konsep dan Praktek di Berbagai Negara, Jakarta: BI.

Asykarya., Diana Y. 2005. Bank Syariah; Gambaran umum, Pusat Pendidikan dan Studi Kebanksentralan (PPSK), Jakarta : BI.

Atang Abd., Hakim. 2011. "Fiqih Perbankan Syari'ah", Bandung: PT Rafika Aditama.

Choudhury M. Alam. 1986. Contribution to Islamic Economic Theory, New York: St. Martin's Press.

Didik A.S. 2013. Sistem Lembaga Keuangan Ekonomi Syari'ah Dalam Pemberdayaan
Ekonimi Rakyat, Surabaya: PT Pustaka Rizki Putra.

Maulana. 2011. "Pelaksanaan Pembiayaan Mudharabah (Studi Kasus Pelaksanaan Pembiayaan Mudharabah Pada Koprasi BMT Bintoro Madani Demak)". Semarang: Fakulatas Agama Islam Syari'ah, UNISSULA

Miskiyatus Sariroh. 2011. "Pelaksanaan Mudharabah Di BNI Syari'ah Cabang Bandung Tahun 2009 (Studi kasusu Akad pembiayaan Mudharabah Nomor: SMS/027/2009/Mudharabah

Syari'ah. Bandung: Fakultas Agama Islam, Syari'ah. Universitas Islam Bandung.

Muhammad Syafi'I Antonio. 2010. Bank Syariah dari Teori ke Praktik, Jakarta: Gema Insani.

Murasa S. 2009 Ruqyah Syar'iyyah ; teori, model dan sistem ekonomi islam, Cirebon: STEI Al-Ishlah Cirebon Press.

Rivai., Veithzal. 2010. 'Islamic Banking: sebuah teori, konsep, dan aplikasi'.' Bumi Aksara, Jakarta,

Otoritas Jasa Keuangan., BI, .2016. Statistik Perbankan Syariah, link : http://www.ojk.go.id/id/kanal/perbankan/ data-dan-statistik/statistik-perbankanindonesia/Default.aspx

Wiroso. 2011. Produk Perbankan Syariah, Jakarta: LPFE, Usakti. 